\title{
Research on the Innovation Impact of Government Guidance Fund on Dongguan Intelligent Manufacturing
}

\author{
He Wenqin; Xiao Zengyan* \\ City College of Dongguan University of Technology, Dongguan, China \\ Corresponding author
}

\begin{abstract}
Government guidance fund is an effective way to financially support intelligent manufacturing upgrading, and it can become an important financing channel for Dongguan intelligent manufacturing enterprises. Based on the development status of Dongguan intelligent manufacturing and the guidance fund collected from the Private Equity database invested in Dongguan intelligent manufacturing enterprises, this article studies the innovation impact of Dongguan intelligent manufacturing industry on broadening financing channels and improving enterprises quality.
\end{abstract}

Keywords-Dongguan intelligent manufacturing; government guidance fund; financing

\section{INTRODUCTION}

Intelligent manufacturing is the main direction of Made in China 2025, and it is also the only way for Dongguan manufacturing industry to break through. Dongguan City is the first to propose to focus on building an overhaul ecological chain of intelligent manufacturing, promote the transformation of manufacturing to intellectual creation, and strive to leap forward. The first part in this article introduces the development status in the transformation such as that the insufficient supply of funds does not match the financial environment, etc. The second part discusses the usage of government guidance funds in Dongguan intelligent manufacturing industry from the aspects of quantity and benefit, and finally summarizes the government guidance fund has an innovation impact on Dongguan intelligent manufacturing.

\section{STATUS QUO OF DONGGUAN INTELLIGENT MANUFACTURING DEVELOPMENT}

\section{A. The Intelligentization Process Is In Good Condition Generally}

As a national deep integration of Industrialization \& informatization and intelligent manufacturing test area, Dongguan has achieved rapid development in recent years1. According to the Dongguan City Government Work Report in 2017, Dongguan took the lead in docking the national strategy to implement the Dongguan Manufacturing 2025 strategy, proceed Six Major Projects such as intelligent manufacturing, and deeply implement the Machine Substitution in Guangdong Province. Two new nationally known demonstrative zones and

Funded by the Young Teachers Development Fund of the City College of Dongguan University of Technology (2018QJZ002R)
34 provincially professional towns were added. The number of engineering or technical centers and famous brand enterprises at provincial level and above reached 247 and 558 respectively, with an increase of $165.6 \%$ and $62.7 \%$ respectively. The transformation and upgrading of intelligent manufacturing enterprises is progressing steadily.

\section{B. High Financial Pressure of Enterprises in the Intelligent Upgrading}

With the deepening of the industrial transformation and upgrading process, the demand for financing is also growing. In the intelligent transformation, the Dongguan municipal government is expected to raise 10 billion Yuan. Take Machine Substitution as an example, not every company has enough financial resources to purchase machinery and robots. Financing difficulties and high funding thresholds have become a problem in front of many intelligent manufacturing companies. The private loan mechanism in Dongguan is still not perfect. Lending institutions is small in both number and scales. In addition, venture capital and private placement are not active. All these result in Anemia in Dongguan industrial upgrading and those traditional manufacturing companies have difficulty getting investors' attention.

\section{Lack of Financially Supported Innovative Products on Intelligent Manufacturing}

The financial policy guidance of Dongguan Intelligent Manufacturing is very clear, but basically stays on the oriented support, and it is urgent to deepen financial innovation, including innovation of financing products and financial system2. Many of the intelligent manufacturing enterprises in Dongguan are in the initial stage with many uncertain factors. The financing demand has the characteristics of high risk and high return. There are few financial products customized for intelligent manufacturing enterprises. In the perspective of financial services, the homogenization is serious. There exists low-level duplication. And large amounts of credit funds are blindly invested in the same big projects and large enterprises, thus the financing needs of small ones are unable to meet, and finally it reduces the allocation efficiency of financial resources. 
III. The Analysis of the Government Guidance Fund INVESTED IN DONGGUAN INTELLIGENT MANUFACTURING

\section{A. Analysis of the number of government guidance fund}

The manufacturing enterprises in Dongguan are limited in scale and have insufficient fixed assets. There are externality and information asymmetry in the financing process. The allocation of resources in the market mechanism does not work sometimes, and it may need to be jointly invested by government venture capital and private venture capital to promote the growth of enterprises3. Through the policy guidance fund, the Dongguan government is fully committed to developing low-end manufacturing and promoting the transformation and upgrading of the manufacturing industry. According to statistics from the Private Equity of the Zero2IPO Research Center, as of September 27, 2018, Dongguan has a total of 12 government-directed funds invested in manufacturing enterprises. The total fund amount exceeds 15 billion Yuan, effectively guiding social capital into the transformation and upgrading of the intelligent manufacturing industry.

TABLE I. RECENT DONGGUAN GOVERNMENT GUIDANCE FUNDS

\begin{tabular}{|c|c|c|c|}
\hline Date & Fund Name & Amount & Key Assistant Fields \\
\hline 10-Apr-13 & Dongguan Red Earth Fund & 500 Million RMB & Growth-Type enterprises, emerging Industries of Strategic Importance \\
\hline 26-May-13 & $\begin{array}{l}\text { Zhongke Zhongguang Dongguan } \\
\text { Equity Investment Fund }\end{array}$ & 550 Million RMB & $\begin{array}{l}\text { Dongguan industrial transformation and upgrading projects such as energy } \\
\text { saving and environmental protection, industrial upgrading and consumption } \\
\text { upgrading }\end{array}$ \\
\hline 10-May-14 & Dongguan Innovation Seed Fund & 50 Million RMB & Seed-stage, initial stage technology-based enterprises \\
\hline 01-Jan-15 & $\begin{array}{l}\text { Dongguan Science and Technology } \\
\text { Achievement Transformation } \\
\text { Guidance Fund }\end{array}$ & 600 Million RMB & Technology-based SMEs \\
\hline 23-Jun-15 & $\begin{array}{l}\text { Changan Industrial Equity } \\
\text { Investment Fund }\end{array}$ & 200 Million RMB & Growth-Type SMEs in mold and hardware industry \\
\hline 10-Oct-15 & $\begin{array}{l}\text { Dongguan City Boshi Rui Dexin } \\
\text { Robot Equity Investment Center }\end{array}$ & 500 Million RMB & $\begin{array}{l}\text { Industrial robots and intelligent equipment, industrial automation, servic } \\
\text { and special robots industries }\end{array}$ \\
\hline 10-May-16 & Changping Shengjing Fund & 100 Million RMB & New Third Board SME \\
\hline 13-Jul-16 & $\begin{array}{l}\text { Guangdong Dongguan } \\
\text { Entrepreneurs Qingda Equity } \\
\text { Investment Fund }\end{array}$ & 800 Million RMB & $\begin{array}{l}\text { Emerging Industries of Strategic Importance such as smart equipment, } \\
\text { electronic information, environmental protection, new materials, and new } \\
\text { energy }\end{array}$ \\
\hline 30-Sep-16 & $\begin{array}{l}\text { China's Third Generation } \\
\text { Semiconductor Fund }\end{array}$ & 2 Billion RMB & $\begin{array}{l}\text { The upstream, middlestream and downstream innovative enterprises of The } \\
\text { third generation of semiconductor technology }\end{array}$ \\
\hline 26-Dec-17 & Mayong Development Fund & Unveiled & Planned industry for Mayong Town Development \\
\hline 11-Jul-17 & Daojiao Emerging Fund & 300 Million RMB & Daojiao manufacturing and emerging industries \\
\hline 20-Jun-17 & Dongguan Shijie Haifu Fund & 5 Billion RMB & Electronic components, e-commerce industry, etc. \\
\hline \multicolumn{3}{|c|}{$\begin{array}{l}\text { B. Analysis of the Benefits of Government Guidance Fund } \\
\text { With the rapid growth of the Dongguan government } \\
\text { guidance fund in number and scales, it has played a positive } \\
\text { role in supporting intelligent manufacturing development, } \\
\text { improving the investment environment and Dongguan }\end{array}$} & $\begin{array}{l}\text { Source: Private Equity of the Zero2IPO Research Center, September 27, 2018 } \\
\text { conomic strength, etc. In view of the development } \\
\text { haracteristics of the intelligent manufacturing industry and } \\
\text { arning from Tian Juanjuan's research4, this article analyzes } \\
\text { e benefits of the Dongguan government guidance fund from } \\
\text { e view of policy achievement, enterprise benefit and social } \\
\text { enefit. }\end{array}$ \\
\hline
\end{tabular}

TABLE II. .BENEFIT EVALUATION OF GOVERNMENT GUIDANCE FUNDS IN THE PAST THREE YEARS

\begin{tabular}{|c|c|c|}
\hline Item & Index & Annual Average Value \\
\hline \multirow{2}{*}{ Policy Achievement } & \begin{tabular}{|l}
$\begin{array}{l}\text { The government guidance funds amount invested in intelligent } \\
\text { manufacturing }\end{array}$ \\
\end{tabular} & 1.83 Billion RMB \\
\hline & $\begin{array}{|lllll|}\begin{array}{l}\text { The driven industry funds amount invested in intelligent } \\
\text { manufacturing }\end{array} & & & \\
\end{array}$ & Exceed 8 Billion RMB \\
\hline \multirow{3}{*}{ Business Benefit } & Employment growth rate in intelligent manufacturing & $0.44 \%$ \\
\hline & $\begin{array}{l}\text { Growth rate of research and development results in intelligent } \\
\text { manufacturing industry (taking invention patent authorization as an } \\
\text { example) }\end{array}$ & $46.28 \%$ \\
\hline & Intelligent manufacturing industry value-added growth rate & $13.27 \%$ \\
\hline \multirow{3}{*}{ Social Benefit } & Tax contribution growth rate & $17.17 \%$ \\
\hline & Value-added growth rate of the financial industry & $6.87 \%$ \\
\hline & Fixed asset investment growth rate & $7 \%$ \\
\hline
\end{tabular}


IV. The InNovation Impact of Government Guidance Fund ON DONGGUAN INTELLIGENT MANUFACTURING

\section{A. Breaking through the Financing Difficulties of Intelligent Manufacturing}

The government guidance fund is an important policy tool to solve market failures, promote industry development, foster investment institutions, and improve the innovation environment of enterprises5. The transformation and upgrading of traditional manufacturing industry first need innovative financial means to guide social capital to focus on key fields such as intelligent manufacturing. The government guidance fund is an effective way to promote the Dongguan economic transformation and upgrading in the New Era. It is essentially a financing medium that introduces new blood to intelligent manufacturing companies through financial capital. By exerting the leverage effect of fiscal funds and guiding social capital to participate in venture capital investment, it can not only accelerate the integration of industry and finance, but also deepen the original banking and financing mechanism, guide funds to better serve the intelligent manufacturing, and broaden corporate financing channels. It is conducive to discovering and nurturing emerging industries and strengthening basic industries.

\section{B. Improving the Development Quality of Intelligent Manufacturing Enterprises}

The key to the development of intelligent manufacturing is to break through the thinking and develop a new model of integration of industry and finance, and the government guidance fund is the main path to achieve integration of industry and finance6. Government guidance funds use financial innovation as a breakthrough to promote science, technology and systems to jointly support the development of manufacturing enterprises, promote the equity of corporate assets to increase liquidity, promote the accumulation of highquality capital, projects, technologies and talents to Dongguan, accelerate the transformation and upgrading of Dongguan industry and innovative economic pace. Under the impetus of the government guidance fund, the combination of industry and finance, technology and capital, improved the core competitiveness of manufacturing enterprises, and thus improve the quality of their development.

\section{Accelerating the Transformation and Upgrading of Intelligent Manufacturing}

The government guidance fund reflects the orientation of government policies and can actively mobilize various resources to a greater extent, and then promote the transformation and upgrading of the manufacturing industry. Through leverage to amplify the effect of fiscal funds, improve the accuracy of financial assistance funds, and focus on key fields and weak sectors in the development of intelligent manufacturing in a market-oriented manner. On the one hand, it promotes the reform of traditional manufacturing, increases industrial restructuring, and mergers and acquisitions of enterprises, which helps to adjust the economic structure, industrial structure and optimal allocation of resources; on the other hand, through government guidance and demonstration, it can stabilize market expectations and accelerate the implementation of innovation-driven development strategy.

\section{CONCLUSION}

This article analyzes the investment status of government guidance funds in intelligent manufacturing in Dongguan through the aspects of quantity and benefit, and deeply analyzes the innovation impact of government guidance funds. It is not only the innovation of investment and financing mechanism of intelligent manufacturing enterprises, but also the new power for Dongguan intelligent manufacturing transformation and upgrading in the New Era. Dongguan government further enhances the efficiency of the government guidance funds and promotes the sustainable and rapid development of intelligent manufacturing.

\section{REFERENCES}

[1] Zhang Zhimin. On Dongguan Intelligent Manufacturing Development. Special Zone Economy [J], 2015:22-26

[2] Yang Dongyun, Dong Benxin. Support and Performance Evaluation of Financial System for Transformation and Upgrading of Manufacturing Enterprises [J], China International Business, 2018:252

[3] Dong Jianwei, Wang Han, Guo Lihong. The Impact of Government Guide Fund Local Investment on Corporate Innovation [J].Science \& Technology Progress and Policy, 2018(3):116-12

[4] Tian Juanjuan. On Performance Evaluation of Industry-Oriented Government Guide Fund-Taking Strategic Emerging Industries as an Example [J], Journal of Liaodong University :Social Sciences, 2018(2):38-45

[5] Cheng Conghui, Wang Siliang, Can a Venture Capital Government Duide Fund Instruct Entrepreneurs to Innovate? [J]. Studies in Science of Science, 2018(8):1466-1473

[6] China Construction Bank Investment Co., Ltd. Investment Research Institute. Annual Report on the Development of China's Investment [D].Social Sciences Academic Press(CHINA), 2017:166-176 